\title{
RECONSTRUCTING THE PATTERN AND DEPTH \\ OF FLOW ONSHORE IN A PALAEOTSUNAMI \\ FROM ASSOCIATED DEPOSITS
}

\author{
D. E. Smith ${ }^{\mathrm{a}, *}$, I. D. L. Foster ${ }^{\mathrm{b}}$, D. Long ${ }^{\mathrm{c}}$ and S. Shi ${ }^{\mathrm{d}}$ \\ a Oxford University Centre for the Environment, South Parks Road, Oxford OX1 3QY, UK \\ ${ }^{\mathrm{b}}$ School of Business and the Environment, Coventry University, Coventry CV1 5FB, UK and Department \\ of Geography, Rhodes University, Grahamstown 6140, South Africa \\ ${ }^{\mathrm{c}}$ British Geological Survey, West Mains Road, Edinburgh EH9 3LA, UK \\ ${ }^{\mathrm{d}}$ Research and Development Centre, National Laboratory for Information Surveying, Mapping and Remote \\ Sensing, ShenZhen, Guangdong 518051, China
}

\begin{abstract}
The widespread sheets of fine particulate sediment frequently deposited by tsunami constitute valuable evidence from which to reconstruct tsunami inundation. This is illustrated with evidence from three sites near Montrose, in eastern Scotland, U.K., where an horizon of mainly sand, laid down during the Holocene Storegga Slide palaeotsunami of circa $8000 \mathrm{BP}$ is examined. The horizon is remarkably consistent in its distribution, morphology, stratigraphy, and particle size characteristics. These properties allow inferences to be made on the nature of tsunami flow onshore and run-up. It is suggested that estimates can be made of the possible depth of water involved from the characteristics of the sediment, and thus of the extent of inundation involved in the tsunami at these sites.
\end{abstract}

Keywords: Tsunami; Particle size: Tsunami run-up; Sediment run-up; Settling rates

* Corresponding author

E-mail address: davidsmith@quaternary.wanadoo.co.uk

\section{Introduction}

It is well known that the height reached by tsunami at the coast greatly exceeds wave height in the open ocean, often resulting in widespread coastal inundation. However, 
even in modern tsunami, although a number of detailed studies of flooding from individual events have been undertaken, no systematic studies across a range of coastal settings are available, making an understanding of tsunami impact imprecise. As a result, the importance of such factors as offshore bathymetry and onshore topography is only known in general terms and such models as have been developed cannot be validated in detail by empirical evidence. The purpose of this paper is to draw attention to the information that the most characteristic tsunami signature - widespread sheets of fine particulate sediment - may provide in determining the anatomy of the event, including in particular possible flow depth. It takes as an example the sediments deposited by the Holocene Storegga Slide tsunami of circa 8000 BP at three sites in eastern Scotland.

\section{Tsunami deposits in the SW Montrose Basin, Scotland}

2.1 The area. The area examined in detail in this paper lies on the south-western shore of the Montrose Basin, eastern Scotland, UK (Figure 1). The Montrose Basin is an estuarine area at the mouth of the river South Esk, surrounded by marine terraces. The Basin is mesotidal, the present Spring tidal range at Montrose being 4.1m (Admiralty Hydrographic Department, 1996), and recent work suggests that this is likely to have changed little over the mid-late Holocene (Shennan et al., 2000). The area has experienced glacio-isostatic uplift since the last glaciation (e.g. Cullingford and Smith, 1980; Smith and Cullingford, 1985; Smith et al., 2006), with marine terraces at several altitudes, reflecting former shorelines. The highest marine terraces surrounding the Basin were formed during and following the decay of the last (Late Devensian) ice sheet to have occupied the area. These terraces, dissected by a number of gullies, overlook raised 
Holocene estuarine silts to seaward. These silts form a level surface, known locally as "carseland", and for the most part probably a relict saltmarsh. Underlying the silts (carseland) and resting upon Late Devensian deposits beneath is a layer of Holocene peat, which outcrops along the gully sides and at their heads. Within the silts and passing landward into the peat a prominent layer of fine particulate sediment, mainly fine or medium sand, occasionally coarser but with some silt and sometimes containing intraclasts of peat, occurs. For convenience, this layer is referred to as a sand layer in this paper. The silt surface beneath the sand is generally level and on the grounds of its morphology, lithostratigraphy and biostratigraphy is believed to have been the carseland surface that existed before the sand was laid down. The sequence of deposits has been described in a number of accounts (e.g. Cullingford and Smith, 1980; Smith et al., 1980; Smith and Cullingford, 1985), and the sand interpreted as a deposit of the Holocene Storegga Slide tsunami (e.g. A.G. Dawson et al., 1988; Long et al., 1989a; 1989b; Smith et al., 2004).

In the area examined in detail (Figure 2), a total of 62 boreholes made to depths of up to 10m by Smith and Cullingford (1985) and Smith et al. (2004), were supplemented by a further 15 boreholes in the present study. At the time of the tsunami, the area was a coastal embayment, effectively an extension of the Montrose Basin of the time, and the gullies were narrow inlets around that embayment. The sand horizon is extensive and has been identified in a large number of the boreholes, many spaced only a few metres apart. Three sites in this small area will be discussed in detail: gullies at Old Montrose and Fullerton and a bluff section at Maryton. The techniques of investigation are outlined in 
Smith et al. (1980), Smith and Cullingford (1985), Shi (1995) and Smith et al. (2004). Of particular relevance to this paper are particle size (textural) analyses of the tsunami sediment, in which contiguous $1 \mathrm{~cm}$-thick samples were analysed using laser granulometry with samples pre-treated to remove all organic matter. In this paper, altitudes are expressed in terms of British Ordnance Datum Newlyn (OD), with present day Mean High Water Spring Tides Montrose (MHWS) in parentheses.

\subsection{Stratigraphical context of the sand layer and possible direction of tsunami flow.}

Across the embayment, the sand layer is up to $0.5 \mathrm{~m}$ thick, and is remarkably consistent in its thickness and altitude locally, variations between adjacent boreholes being no more than a few centimentres. As it is followed from the sea inland it increases in thickness slightly before decreasing and tapering to disappear in peat at the heads of the gullies. Figure 3 shows sections along and across the gully at Fullerton (A-B and C-D, Figure 2), behind the bluff section at Maryton (E-F, Figure 2) and along the gully at Old Montrose (G-H, Figure 2). The sand layer rests upon underlying estuarine silt towards the mouths of both the Fullerton and Old Montrose gullies, but can be followed upwards into peat at the heads of these gullies. At Fullerton and Old Montrose, Smith et al. (2004) reported maximum observed sediment run-up at, respectively, 3.9m (reaching an altitude of $7.9 \mathrm{~m}$ OD or $5.8 \mathrm{~m}$ MHWS) and $1.2 \mathrm{~m}$ (reaching $6.1 \mathrm{~m}$ OD or $4.0 \mathrm{~m}$ MHWS). This was based upon the highest altitude reached by the sand above the highest altitude of the silt surface beneath. At Maryton, the tsunami sand rests upon a thin $($ circa $20 \mathrm{~cm})$ peat layer overlying basal Late Devensian sediments. Maryton, which comprises mainly a bluff section, lies on what is probably the western side of a former gully, the eastern side of 
which has subsequently been eroded as relative sea levels around the Montrose Basin fluctuated during the middle and late Holocene. The base of the sand layer in the section studied at Maryton is at 4.2m OD (2.1m MHWS).

It seems likely that the tsunami sand was deposited from water that crossed the intertidal surface of the embayment then surged into the gullies when they were inlets in the coastline of the time. A clue to the nature of tsunami flow into this area is provided by the disposition of the sand layer, illustrated for the Fullerton gully in Figure 3 (sections A-B and C-D). Here, the layer is seen to rise in elevation towards the head of the gully, but to be almost level across its width. Indeed, whilst sediment run-up reaches a maximum observed value of $3.9 \mathrm{~m}$ at the head of the gully, the maximum observed run-up value is only $0.4 \mathrm{~m}$ across its width. Across the area in general, the sand layer is level in the embayment but rises to its highest altitude at the heads of the gullies. It is suggested here that this indicates that the momentum of tsunami flow was greatest along the axis of each gully. This observation accords with the observations of Wright and Mella (1963) from south-central Chile following the 1963 Chilean tsunami and with Guiborg et al.'s (1997) modelling of the impact of the 1995 Chilean tsunami in an inlet in French Polynesia. Across the embayment as a whole, the available borehole evidence does not show much variation in the altitude or thickness of the sand layer, even towards the former shoreline.

2.3 Origins of the sand. It seems highly likely that the sand was at least in part derived from local sources, for two reasons. Firstly, there are peat intraclasts present, probably derived from the peat overlying the silt beneath the sand. Secondly, there are extensive 
deposits of fine particulate sediment surrounding the Montrose Basin and offshore. Thus the Late Devensian terraces which largely surround the Montrose Basin are mainly composed of sand and silt, as numerous exposures show (Cullingford and Smith, 1980), while to seaward a barrier composed of sand and gravel overlying a surface of silty clay is present. Crofts (e.g.1980) examined this barrier in detail, while Cullingford and Smith (1985) showed that the barrier was contemporary with the carselands, showing that the barrier was probably present at the time of the tsunami, although the barrier probably did not reach as far south at that time. Offshore the sea bed sediments are sand dominated with typically less than 5\% finer than 63 microns (British Geological Survey, 1986). At the time of the tsunami, mean tidal levels around the basin lay at circa 2-5m OD (circa 03m MHWS) as indicated by the silt surface beneath the sand, thus rendering these areas of sediment subject to erosion and transport by the tsunami waves.

2.4 Particle size analysis and depositional episodes. The sand layer exhibits no structures discernable by eye in either the boreholes or in the available exposures apart from the occasional intraclast of peat, but the particle size analysis as determined by laser granulometry shows the sediment to be well sorted (e.g. Smith et al., 2004). The particle size profile is distinctive. Figure 4 shows particle size analyses for contiguous $1 \mathrm{~cm}$-thick samples from four boreholes towards the head of the gully at Fullerton, previously published in Smith et al. (2004); from the bluff section at Maryton; and from one borehole at Old Montrose. At Fullerton, two fining-upwards sequences are present, the upper sequence decreasing in thickness towards the head of the gully. At this site, most samples have a bimodal particle size distribution, with the finer peak increasing in 
percentage volume towards the top of each sequence as the percentage volume of the coarser peak decreases. At Maryton, bimodality is less pronounced, but two finingupwards sequences are present. At Old Montrose only one sample approaches a bimodal distribution, and a single fining-upwards sequence is present. From the location of the three sites, it appears that there is a pattern of two fining-upwards sequences close to the present Montrose Basin, and one farther inland. In addition, a fining-landwards trend is evident at Fullerton, where four boreholes were analysed. Figure 5 shows mean particle size volume for the two sequences at each borehole in the Fullerton gully, and indicates that for each sequence particle size decreases landward. From the mean particle size values at Fullerton, it would seem unlikely that the two sequences reflect, respectively, run-up and backwash, since mean particle size decreases landward in each sequence (although there is a very slight reversal of this trend in the lower sequence at borehole II). Whilst it is recognised that tsunami flow onshore can be complex (e.g. Shi, 1995), it is argued here that the pattern of fining upwards sequences across this former embayment may indicate that each sequence was the deposit of an individual wave, and that one wave reached farther inland than the other, given that two sequences occur at sites near the basin, but only one at the more protected site. Several authors have correlated a given fining-upwards particle size sequence with one wave (e.g. Dawson et al., 1991; Goff et al., 1998). There is no evidence of erosion of the surface of the lower sequence where two sequences exist. This may be because the area would have been particularly well sheltered. Thus if the complete depositional record is preserved, it seems likely that the site was reached by two waves. 
2.5 Water depth. A striking feature of the particle size profiles is that they show consistent trends, with no major change in sorting towards the surface of the sediment column, indicating that the surface of the water from which the sediment was laid down lay well above. This is corroborated by the disposition of the tsunami sediment, which is apparently continuous over much of the area (only four boreholes out of 51 which lie to seaward of the inland limit having failed to locate the sand), and which is locally consistent in both surface altitude and thickness, as observed above. Several studies of tsunami deposits have remarked on the likelihood that the water surface lay well above sediment sheets deposited (e.g. Shi et al., 1993; 1995a; 1995b; Yeh et al., 1993; Kawata et al., 1999); while others have remarked on the possibility that sand sheets can remain little altered after deposition (Nishimura and Miyaji, 1995). With these observations in mind, it is suggested that the sedimentary characteristics of the tsunami deposit may provide information on the depth of the water in which it accumulated. Recently, Jaffe and Gelfenbaum (2005) have speculated that tsunami sediments may hold the key to estimates of wave height and velocity. In the following paragraphs a suggestion is made as to how flow depth might be estimated.

2.6 Some previous views on the possible deposition of tsunami sand. Previous accounts have speculated on the mode of deposition of tsunami sand sheets. Dawson (1999) and Dawson and Shi (2000) suggested that deposition could occur during "turnaround" periods when an episode of flow into an area briefly ceased before returning seaward. Whilst such periods may occur during tsunami, they are probably short lived, since the evidence of fining-landwards particle size profiles and of the pattern of vegetation 
disturbance within the sediment (e.g. Nishimura and Miyaji, 1995) are difficult to explain with still water conditions. Indeed, deposition from still water during a "turnaround" period implies that the rise of the sand layer up hillsides is a drape rather than a reflection of run-up, contrary to observations in recent tsunami (e.g. Tuttle et al., 2004). Dawson and Shi (2000) have also speculated that deposition could have occurred following tsunami flow in a manner analogous to a turbidity current. There is some support for this in the area studied here in the graded bedding present and in some evidence of erosion of underlying sediments from the peat intraclasts occasionally visible in the sand. However, this interpretation is thought unlikely at the sites examined in the present study, given the lack of a gradient across the widespread intertidal surface which existed before the tsunami and the lack of structures diagnostic of turbidity current deposition in the several exposures along the bluffs at Maryton.

2.7 A possible mechanism for tsunami sand deposition. It is maintained here that at the sites examined, deposition of the sand took place mainly from moving water. Whilst the flow of the water would have been largely turbulent, the lack of erosive features on the surface of the sand layer and the consistent nature of the particle size profiles indicates that turbulence reduced as the tsunami surged onshore. In this area, the surface beneath the tsunami sand is largely of former saltmarsh and areas of mudflat, with peat along the shoreline. Such areas, though not without surface roughness, would have been more level and consistent than most other surfaces encountered by the tsunami, with relatively less friction, and turbulence may have reduced as flow crossed these areas. Further, the water would in all probability have been heavily charged with sand, given the widespread 
availability of sediment in the area as discussed above, thus increasing the dynamic viscosity of the fluid, as standard equations for flow demonstrate (e.g. Richards, 1982). This would also have reduced turbulence.

It is thus suggested here that deposition took place as follows. As each wave of the tsunami flowed onshore, the turbulent water contained a considerable volume of sediment of all sizes. As velocity decreased, turbulence was reduced and the sediment began to settle out. Fining-upwards sequences developed from each wave during this process, with coarser particles settling out first and finer ones later. Backwash carried sediment not deposited back out to sea. The passage onshore of a sheet of water from each wave, heavily laden with sediment gradually settling out in this way would have ensured that a sheet of sediment comprising a fining-upwards sequence would have resulted. Under these circumstances, it is maintained that the rate of accumulation of sediment at a given point may somewhat paradoxically have been analagous to the settling rate in still water since there would have been a continuous supply of sediment coming out of entrainment, from further up-current. It is noted that a number of eye-witness accounts of recent tsunami speak of very high volumes of sediment (e.g. Myles, 1985).

If the considerations articulated above are accepted, then knowing the particle size of the sediment it is possible to estimate at least the minimum depth of water from settling rates. Several methods (e.g. Gibbs et al., 1971) are available to predict the settling velocity of grains in water. These have been recently reviewed by Soulsby (1997), who noted that the Gibbs et al. (1971) settling velocity equation was limited to spherical grains only and 
proposed the use of an alternative equation to predict settling velocities of irregular grains based on optimising two coefficients in a combined viscous plus bluff-body drag law against data for irregular grains (Soulsby ibid., p.134). From Soulsby,

Ws $=v / d\left[\left(10.36^{2}+1.049 D *{ }^{3}\right)^{0.5}-10.36\right]$ for all $D *$ Eq. 1

Where:

Ws = settling velocity

$v=$ kinematic viscosity

$\mathrm{d}=$ median sieve diameter of grains

$\mathrm{D} *=$ Dimensionless Grain Size calculated from:

$\mathrm{D} *=\frac{[\mathrm{g}(\mathrm{s}-1)]^{0.333} \mathrm{~d}}{\left[\mathrm{v}^{2}\right]}$

Where:

$\mathrm{g}=$ acceleration due to gravity $\left(9.81 \mathrm{~ms}^{-2}\right)$

$\mathrm{s}=$ the ratio of the density of grain and water

d and $v$ are defined in Eq. 1

It is suggested that the time taken for the finest particles to settle out individually is likely to be the most diagnostic of water depth because these particles will have taken the longest time to settle. From the particle size profiles in this study, it is concluded that these particles were those of the fine sand fraction, which constitutes most of the sediment by volume. Finer particles recorded may well have been deposited by flocculation (e.g. see McCave et al., 1995), given that the water was saline, or may have been subject to adhesion by organic material (see for example Droppo, 2001), as implied by the occasional presence in the tsunami deposit of fragments of organic material recorded in boreholes and in the section at Maryton. 
The time available for the fine sand in the tsunami deposit to settle from a flooding episode is critical. Assuming that each fining upwards sequence relates to a wave, the time for each sequence would relate to a wave period, although a wave period would be the maximum time, since deposition would not commence until the flow velocity fell to the point where sediment could begin to settle, and a full wave period may not have been achieved close to the shore due to wave reflection. Wave periods in modern tsunami have been estimated by a number of authors, notably Murty (1977), and generally range between 10 and 100 minutes. Wave periods remain the same as the waves approach the shore, as standard texts observe (e.g. Komar, 1976). Table 1 gives the range of water depths for periods of between 10 and 100 minutes for the finest fine sand (the finest particles likely to have settled out individually) based upon equation 1, above, of Soulsby (1997) and assuming a salinity of $35 \%$, a temperature of $10^{\circ} \mathrm{C}$ and water and sediment densities of respectively 1027 and $2650 \mathrm{~kg} \mathrm{~m}^{-3}$.

The water depth indicated by the sediments would have been that which obtained above the intertidal surface at the time. In the area involved, borehole logs show that the buried saltmarsh surface (perhaps with some areas of mudflat) beneath the tsunami sand horizon ranges between $3.0 \mathrm{~m}$ and $4.7 \mathrm{~m}$ OD $(0.9 \mathrm{~m}$ to $2.6 \mathrm{~m}$ MHWS). From Table 1 , the range of water depths above this horizon inferred on the basis of the possible range of wave periods and settling rates of the finest fine sand is $1.2 \mathrm{~m}$ to $13.0 \mathrm{~m}$. Harbitz (1992, Figure 11) modelled a wave pattern for the tsunami which developed from what was at the time termed the Second Storegga Slide (the Holocene Storegga Slide), which in the area offshore of Montrose saw a small leading elevation wave followed by a major fall in 
water levels then a major crest followed by later waves. The wave period modelled was approximately 60 minutes. Later, Bondevik et al. (2005, Figure 2) modelled a different wave pattern but a similar wave period. Taking 60 minutes as a possible wave period, a water depth of $7.2 \mathrm{~m}$ is obtained (Table 1 ), thus $10.2 \mathrm{~m}$ to $11.7 \mathrm{~m}$ OD $(8.1 \mathrm{~m}$ to $11.9 \mathrm{~m}$ MHWS) above the saltmarsh surface reached directly before the tsunami in the area. The maximum observed sediment run-up value for Fullerton of 3.9m would imply a tsunami run up of $11.1 \mathrm{~m}$ (7.2m plus $3.9 \mathrm{~m})$, reaching a maximum altitude of $15.1 \mathrm{~m}$ OD (13.0m MHWS). These are maximum figures for the height of the water surface because they assume that settling took place during the entire 60 minutes of the wave period, whereas as indicated above, settling would not begin until the velocity of the water slowed to allow it to take place, and at the shore the residence time of the wave would have been reduced by reflection. The estimate of 60 minutes for the wave period would reduce the likelihood of disruption of the wave pattern over short distances as outgoing waves met incoming ones, thus allowing the consistent pattern of sedimentation to be achieved.

\section{Conclusion}

Detailed study of a sand sheet laid down during the Holocene Storegga Slide tsunami near Montrose, eastern Scotland, UK discloses that in this area:

1. The tsunami deposit was probably derived from local sources.

2. Flooding took place from two waves.

3. When the tsunami reached the gully areas, the momentum of flow was concentrated along the axes of the gullies. 
4. Particle size profiles of the tsunami sand indicate that the water surface lay well above the sediment surface.

5. The tsunami flow onshore became increasingly less turbulent as the water surged into the embayment and then into the gullies along the shoreline.

6. Deposition of the tsunami sediment took place in this area primarily during runup.

7. The consistency in particle size trends allows assumptions to be made about settling rates of the sediment, which indicate that the maximum height of the water surface above the sediment may have reached $7.2 \mathrm{~m}$, with a maximum runup of the tsunami at the sites studied of $11.1 \mathrm{~m}$.

From this local study, it is concluded that study of the distribution, morphology, stratigraphy and particle size (textural) characteristics of the sheets of fine particulate sediment associated with palaeotsunami may provide considerable detail on the anatomy of these events. In particular, it may be possible to infer patterns and depths of flow. This may, in turn, enable a better understanding of the impact of such events to be achieved.

\section{Acknowledgements}

The authors express their gratitude to the many colleagues with whom they have worked on tsunami sedimentation. DES acknowledges the award of a Leverhulme Trust Emeritus Fellowship. DL publishes with permission of the Executive Director, British Geological Survey (NERC). Thanks are due to Professor Richard Soulsby, who provided valuable advice on the processes of sedimentation and to Dr Ian Droppo, who provided essential information on particle settling. Cartographic work was undertaken by Mr Stuart Gill, of 
SCG Cartographics. This paper is a contribution to IGCP Project 495 Quaternary LandOcean Interactions.

\section{References}

Admiralty Hyrdrographic Department. 1966. Admiralty Tide Tables, Volume 1: European Waters including the Mediterranean Sea. Hydrographer of the Navy, Taunton.

Atwater, B.F. 1987. Evidence for great Holocene earthquakes along the outer coast of Washington. Science 236, 942-944.

Atwater, B.F. and Hemphill-Haley, E. 1997. Recurrence intervals for great earthquakes of the past 3500 years at northeastern Willapa Bay, Washington. U.S. Geological Survey Professional Paper 1536, 108pp.

Atwater, B.F. and Moore, A.L. 1992. A tsunami about 1000 years ago in Puget Sound, Washington. Science 258, 1614-1617.

Bondevik, S., Løvholt, F., Harbitz, C., Mangerud, J., Dawson, A. and Svendsen, J.I. 2005. The Storegga Slide tsunami - comparing field observations with numerical solutions. Marine and Petroleum Geology 22, 195-208. 
British Geological Survey. 1986. Tay-Forth $56^{\circ} \mathrm{N}-04^{\circ} \mathrm{W}$ Sea Bed Sediments 1:250 000 map series.

Crofts, R.S. 1980. Coastal processes and sediment around St Cyrus. In Marren, P. (ed.): The Natural History of St Cyrus. Nature Conservancy Council, Edinburgh, 16-26.

Cullingford, R.A. and Smith, D.E. 1980. Late Devensian raised shorelines in Angus and Kincardineshire, Scotland. Boreas 9, 21-38.

Dawson, A.G. 1999. Linking tsunami deposits, submarine slides and offshore earthquakes. Quaternary International 60, 119-126.

Dawson, A.G. and Shi, S. 2000. Tsunnami deposits. Pure and Applied Geophysics 157, 875-897.

Dawson, A.G., Long, D. and Smith, D.E. 1988. The Storegga Slide: evidence from eastern Scotland for a possible tsunami. Marine Geology 82, 271-276.

Dawson, A.G., Foster, I.D.L., Shi, S., Smith, D.E. and Long, D. 1991. The identification of tsunami deposits in coastal sediment sequences. Science of Tsunami Hazards 9, 73-82.

Droppo, I.G. 2001. Rethinking what constitutes suspended sediments. Hydrological Processes 15, 1551-1564. 
Gibbs, R.J., Matthews, M.D. and Link, D.A. 1971. The relationship between sphere size and settling velocity. Journal of Sedimentary Petrology 41 (1), 7-18.

Goff, J.R., Crozier, M., Sutherland, V., Cochran, U. and Shane, P. 1998. Possible tsunami deposits from the 1855 earthquake, North Island, New Zealand. In: Stewart, I.S. and Vita-Finzi, C. (Eds.) Coastal Tectonics. Special Publication, Geological Society of London, 133, 353-374.

Guiborg, S., Heinrich, P. and Roche, R. 1997. Numerical modelling of the 1995 Chilean tsunami: impact on French Polynesia. Geophysical Research Letters 24 (7), 775-778.

Harbitz, C.B. 1992. Model simulations of tsunamis generated by the Storegga Slides. Marine Geology 105, 1-21.

Jaffe, B. and Gelfenbaum, G. 2005. The importance of studying tsunami sediments. USGS Western Coastal and Marine Geology website: http://walrus.wr.usgs.gov/peru2/importance.html

Kawata, Y.B., Benson, L., Borrero, H., Davies, W., de Lange, F., Imamura, H., Letz, H., Nott, J. and Synolakis, C. 1999. Tsunami in Papua New Guinea was as intense as first thought. Eos, Transactions, American Geophysical Union 80, 101-105. 
Komar, P. 1976. Beach processes and sedimentation. Prentice-Hall, Englewood Cliffs.

Long, D., Dawson, A.G. and Smith, D.E. 1989a. Tsunami risk in northwestern Europe: a Holocene example. Terra Nova 1, 532-537.

Long, D., Smith, D.E., and Dawson, A.G. 1989b. A Holocene tsunami deposit in eastern Scotland. Journal of Quaternary Science 4, 61-66.

Matsutomi, H., Shuto, N., Imamura, F. and Takahasi, T. 2001. Field Survey of the 1996 Irian Jaya Earthquake Tsunami in Biak Island. Natural Hazards 24, 199-212.

McCave, I.N., Manighetti, B. and Robinson, S.G. 1995. Sortable silt and live sediment size/composition slicing: parameters for palaeocurrent speed and palaeoceanography. Palaeoceanography 10 (3), 593-610.

Murty, T.S. 1977. Seismic Sea Waves: Tsunamis. Bulletin 198, Department of Fisheries and the Environment: Fisheries and Marine Service, Ottawa, Canada. 337pp.

Myles, D. 1985. The Great Waves. Hale, London.

Nishimura, Y. and Miyaji, N. 1995. Tsunami deposits from the 1993 Southwest Hokkaido earthquake and the 1640 Hokkaido Komagate eruption, northern Japan. Pure and Applied Geophysics 144 (3/4), 719-733. 
Papadopoulos, G.A. 1998. A tsunami catalogue of the area of Greece and adjacent seas. EC Project GITEC-TWO. Institute of Geodynamics, National Observatory of Athens, Publication no. 8.

Richards, K.S. 1982. Rivers. Methuen, London.

Shennan, I., Lambeck, K., Flather, R., Horton, B., McArthur, J., Innes, J., Lloyd, J., Rutherford, M. and Wingfield, R. 2000. Modelling western North Sea palaeogeographies and tidal changes during the Holocene. In Shennan, I. and Andrews, J.E. (eds.): Holocene land-ocean interaction and environmental change around the western North Sea. Geological Society Special Publication 166, 299-319.

Shi, S. 1995. Observational and Theoretical aspects of Tsunami Sedimentation. PhD thesis, Coventry University, Coventry, UK.

Shi, S., Dawson, A.G. and Smith, D.E. 1993. Geomorphological impact of the Flores tsunami of $12^{\text {th }}$ December, 1992. Tsunami '93: International Union of Geodesy and Geophysics/International Oceanographic Commission Proceedings, Wakayama, 689-696.

Shi, S., Dawson, A.G. and Smith, D.E. 1995a. Coastal sedimentation associated with the December 12 192 th 1992 tsunami in Flores, Indonesia. Pure and Applied Geophysics 144, 525-536. 
Shi, S., Dawson, A.G. and Smith, D.E. 1995b. Geomorphological impact of the Flores tsunami of $12^{\text {th }}$ December 1992. In: Tsuchiya, Y. and Shuto, N. (Eds.) Tsunami: progress in prediction, disaster prevention and warning. Kluwer, Dordrecht, pp.187-195.

Smith, D.E. and Cullingford, R.A. 1985. Flandrian relative sea-level changes in the Montrose Basin area. Scottish Geographical Magazine 101, 91-104.

Smith, D.E., Morrison, J., Jones, R.L. and Cullingford, R.A. 1980. Dating the Main Postglacial Shoreline in the Montrose area, Scotland. In: Cullingford, R.A., Davidson, D.A. and Lewin, J. (Eds.) Timescales in Geomorphology. Wiley, Chichester, 225-245.

Smith, D.E., Shi, S., Cullingford, R.A., Dawson, A.G., Dawson, S., Firth, C.R., Foster, I.D.L., Fretwell, P.T., Haggart, B.A., Holloway, L,K, and Long, D. 2004. The Holocene Storegga Slide tsunami in the United Kingdom. Quaternary Science Reviews 23, 22912321.

Smith, D.E., Fretwell, P.T., Cullingford, R.A. and Firth, C.R. 2006. Towards improved empirical isobase models of Holocene land uplift for mainland Scotland, UK. Philosophical Transactions of the Royal Society A, 364, 949-972.

Soulsby, R. 1997. Dynamics of Marine Sand. HR Wallingford and Department of Environment and Transport for the Regions. Thomas Telford, London. 
Tinti, S., Maramai, A. and Graziani, L. 2001. A new version of the European tsunami catalogue: updating and revision. Natural Hazards and Earth System Sciences 1, 255-262.

Tuttle, M.P., Ruffman, A., Anderson, T. and Jeter, H. 2004. Distinguishing Tsunami from Storm Deposits in Eastern North America: The 1929 Grand Banks Tsunami versus the 1991 Halloween Storm. Seismological Research Letters 75(1), 117-131.

Wright, C. and Mella, A. 1963. Modifications to the soil pattern of south-central Chile resulting from seismic and associated phenomena during the period May to August 1960. Bulletin of the Seismological Society of America 53 (6), 1367-1402.

Yeh, H., Imamura, F., Synolakis, C., Liu, P. and Shi, S. 1993. The Flores Island tsunamis. Eos, Transactions, American Geophysical Union 74 (33), 369-373.

\section{Table}

Table1

Inferred range of water depths for deposition of the finest fine sand (of particle diameter $0.06 \mathrm{~mm}$ ) for given wave periods.

\begin{tabular}{|c|c|}
\hline Wave period, minutes & Depth, $\mathbf{~}$ \\
\hline 10 & 1.2 \\
\hline 20 & 2.4 \\
\hline 30 & 3.6 \\
\hline 40 & 4.8 \\
\hline 50 & 6.0 \\
\hline 60 & 7.2 \\
\hline 70 & 8.4 \\
\hline
\end{tabular}




\begin{tabular}{|r|r|}
\hline 80 & 9.6 \\
\hline 90 & 10.8 \\
\hline 100 & 13.0 \\
\hline
\end{tabular}

\section{Figures}

\section{Figure 1}

Location of the area examined.

\section{Figure 2}

Morphological setting of the area examined west of the Montrose Basin, Scotland, showing borehole/section locations and the lines of sections illustrated in Figure 3.

\section{Figure 3}

Sections at Fullerton (A-B, C-D), Maryton (E-F) and Old Montrose (G-H). Based on Smith et al. (1980) and Smith and Cullingford (1985). I - VI denote boreholes/section from which the sand layer was analysed.

\section{Figure 4}

Particle size profiles for the sand layer at Fullerton and Old Montrose and from the bluff section at Maryton. The Fullerton profiles are reprinted from Smith et al. (2004) Quaternary Science Reviews, Figure 8, with permission from Elsevier.

\section{Figure 5}

Mean particle size values for the two sequences in sand layer at the Fullerton gully. 